\title{
Exploring Futures of Ecosystem Services in Cultural Landscapes through Participatory Scenario Development in the Swabian Alb, Germany
}

\author{
$\underline{\text { Tobias Plieninger }}^{1,2}$, Claudia Bieling $^{3}, \underline{\text { Bettina Ohnesorge }}^{1}$, Harald Schaich $^{3}$, Christian Schleyer $^{1,4}$ and Franziska Wolff $^{5}$
}

\begin{abstract}
Cultural landscapes are appreciated for the plethora of ecosystem services that they provide to society. They are, however, subject to rapid and fundamental transformations across Europe, mainly as a result of intensification or abandonment of land uses. Our objective is to assess the possible future drivers of cultural landscape changes and their likely impacts on ecosystem services provision as perceived by local actors. We present stakeholder-based scenarios for the Swabian Alb, a biosphere reserve in southern Germany, projected to the yr 2040. On their basis, we explore the possibilities and limitations of local civil engagement for landscape conservation and development in the face of increasing global influences. The steps of the process are (a) identifying the key driving forces of landscape change, (b) developing contrasting narratives about alternative landscape futures, (c) refining the narratives, (d) discussing scenario impacts, and (e) exploring local management strategies. Four contrasting scenarios created by the stakeholders are presented. Global-level drivers are state support/regulations vs. freemarket economy, and energy-intensive lifestyles vs. low-energy economy. Local-level forces are high vs. low consumer demand for localized food, and high vs. low appreciation of local cultural landscapes. Outcomes show that cultural landscape development may come to a crossroads over the next $30 \mathrm{yrs}$, with either combined land abandonment and landscape industrialization scenarios or multifunctional, locally distinct landscape futures being possible. The scenario narratives envision that the most powerful way to develop and protect distinct landscapes is to foster local people's links to cultural landscapes, to build social capital around them, and to direct consumption patterns toward localized food production. We find that participatory scenario processes have strengths in terms of the credibility, transferability, and confirmability of the insights gained, but are often weak in ensuring dependability.
\end{abstract}

Key Words: ecosystem services: landscape development ; participatory scenario planning; Germany; multifunctional landscapes; regional development; quality of life; rural areas

\section{INTRODUCTION}

European cultural landscapes are valued as everyday living environments, countryside, heritage, scenery with aesthetic and recreational qualities and unique biodiversity, and as a source of ecosystem services that they provide to society (Farina 2000, Plieninger and Bieling 2013). However, cultural landscapes are undergoing rapid and fundamental transformations across Europe, mainly as a result of an ongoing polarization of land use, with abandonment and rural exodus on the one hand, and intensification and (peri-) urbanization on the other (Verburg et al. 2010). The processes of cultural landscape change are driven by changes in institutional arrangements, demography, policies, economic conditions, and climate, and have resulted in the gradual replacement of traditional landscape practices by standardized and mechanized land uses. Although the specific drivers and outcomes of these processes vary across Europe, a central tendency is the fundamental decoupling of the sociocultural and ecological subsystems in cultural landscapes (Fischer et al. 2012, Selman 2012). This leads to the degradation of landscape values and renders the future of many cultural landscapes highly uncertain.
The protection, management, and planning of cultural landscapes has attracted broad attention from scientists, policy makers, and the general public subsequent to the adoption of the European Landscape Convention (ELC) in 2000 (Jones 2007). Increasingly, efforts are being made to preserve the regional diversity and value of cultural landscapes while seeking to identify pathways to a more sustainable future. Today, the diversity, along with the place-specific character, of cultural landscapes is being emphasized in many European and national conservation and development strategies (PintoCorreia et al. 2006). Local-level action for maintaining cultural landscapes has often been organized through partnerships of land users, conservation activists, and consumers (Prager 2010, Enengel et al. 2011). Trial-testing new bottom-up approaches, these initiatives have aimed at achieving bestpractice examples of sustainable rural development (Peter and Knickel 2006). Regional landscape initiatives often conceive of themselves as locally based counter-movements to globalized agribusiness, and intend to preserve, enhance, or establish localized economic cycles. Their activities include the continuation of traditional farming practices and products, but enhanced through the addition of contemporary

\footnotetext{
${ }^{1}$ Ecosystem Services Research Group, Berlin-Brandenburg Academy of Sciences and Humanities, ${ }^{2}$ Department of Geosciences and Natural Resource Management, University of Copenhagen, ${ }^{3}$ Chair for Landscape Management, University of Freiburg, ${ }^{4}$ Department of Environmental Politics, Helmholtz Centre for Environmental Research - UFZ, ${ }^{5}$ Öko-Institut e.V.
} 
innovations, such as localized production and consumption of biomass energy (Matthews and Selman 2006).

Efforts to preserve cultural landscapes in their "traditional" state have often received criticism regarding their conservative and static worldviews (Renes 2011). Meanwhile, many European cultural landscapes are in a late conservation phase as seen through a resilience lens, meaning that they are at the turning point toward breakup (Plieninger and Bieling 2013). The conventional preservation approach in Europe has been to regulate land uses and pay farmers for maintaining traditional farming practices. However, attempting to maintain the status quo of past land-use systems through financial incentives seems to prevent meaningful experimentation and renewal of landscapes rather than achieving their goal of restoring the intricate cultural embedding of people in their landscape (Burton and Schwarz 2013).

"Scenario techniques" are one way of fostering the selforganization and empowerment of stakeholders, in pursuit of the renewal of cultural landscapes (Wollenberg et al. 2000, Evans et al. 2008). Scenarios, defined as "plausible descriptions of how the future may develop, based on a coherent and internally consistent set of assumptions about key relationships and driving forces" (International Panel on Climate Change 2012), can be used: (1) to enable managers to better understand the forces driving landscape change and work with landscape stakeholders, as well as (2) to improve adaptive capacity, not only by responding to landscape changes, but also by anticipating them. Scenarios answer questions: (1) Precisely how might some hypothetical situation come about, step by step?, and (2) What alternatives exist, for each actor, at each step, for preventing, diverting, or facilitating the process? (Kahn and Wiener 1967:6). Scenario outputs can include narrative storylines (Peterson et al. 2003, Kaljonen et al. 2012), visual simulations (Tress and Tress 2003, Loupa Ramos 2010), maps (Weis and Hülemeyer 2011), and qualitative and quantitative models (Baker et al. 2004). A scenario approach can be particularly valuable when applied in a participatory way (Walz et al. 2007, Pahl-Wostl 2008). Triggering actors to creatively think about possible futures and develop and scrutinize various management options leads to results that are tailored to the real-world situation faced, most notably by incorporating diverging views and interests of stakeholders and locally specific experiential knowledge (Peterson et al. 2003, Henrichs et al. 2010).

Scenario techniques have been successfully applied in European landscape contexts; for example, with foci on protected area management (Palomo et al. 2011), climate change adaptation (Albert et al. 2012), tourism (Loibl and Walz 2010), freshwater resources (Kaljonen et al. 2012), food supply chains (Penker and Wytrzens 2005), and rural development (Van Berkel et al. 2011). Although stakeholders' valuations of different scenario outcomes have frequently been examined (e.g., Lindborg et al. 2009), few studies have addressed, through exploratory scenarios, how local actors perceive the impacts of landscape changes on ecosystem services provision, and how they define their scope for action against the multitude of landscape drivers.

The objective of our present transdisciplinary work is to assess the possible future drivers of cultural landscape changes and their likely impacts on ecosystem services provision as perceived by local actors. We do so by facilitating stakeholderbased scenario development about landscape futures in the Swabian Alb, a biosphere reserve in southern Germany (see Fig. 1), projected into the yr 2040. First, we set the stage by retracing the historical eras of change in the Swabian Alb to highlight the inevitability of change and surprises in the region. We then describe the methodology of scenario development that we pursued. Further, we present insights on local actors' perceptions of quality of life, ecosystem services, and major drivers of change. Based on these drivers, four scenario narratives are generated, including changes in ecosystem services provision, potential beneficiaries and losers, and local-scale management options. Finally, we discuss possibilities for, and limitations of, local civic engagement concerning landscape conservation and development.

\section{THE SWABIAN ALB AS A SOCIAL-ECOLOGICAL SYSTEM}

\section{Ecological system}

The Swabian Alb is part of the largest Jurassic low mountain range in central Europe. Differences in geological formations and topography have built a north-south sequence of biogeographical regions that have defined settlement development, land-use history, and biodiversity distribution (Regierungspräsidium Tübingen 2007). The Swabian Alb Biosphere Reserve $(85,000 \mathrm{ha})$ is situated in the central part of the mountain range. The foothill and escarpment area in the north is characterized by an ascending slope: from Lower and Middle Jurassic formations to steep slopes and gorges built by the Upper Jurassic. The foothills have a mild climate, allowing the presence of orchard meadows and sporadic vineyards. The steep cliff of the escarpment comprises the smallest area but also the most spectacular landscapes of the low mountain range. The plateau region is slightly undulated and comprises many geologic and volcanic features, such as karst-like caves, swallow holes, tuff ring formations, and craters. Calcareous grassland and heathland ecosystems (some of high nature value) dominate, and arable lands are concentrated on the more fertile sites.

\section{Social system}

In 2005, 151,400 inhabitants lived permanently in the Swabian Alb region, as defined by the limits of the biosphere reserve (Regierungspräsidium Tübingen 2007). There are substantial 
Fig. 1. Land-cover map and location of the Swabian Alb study area within Germany.

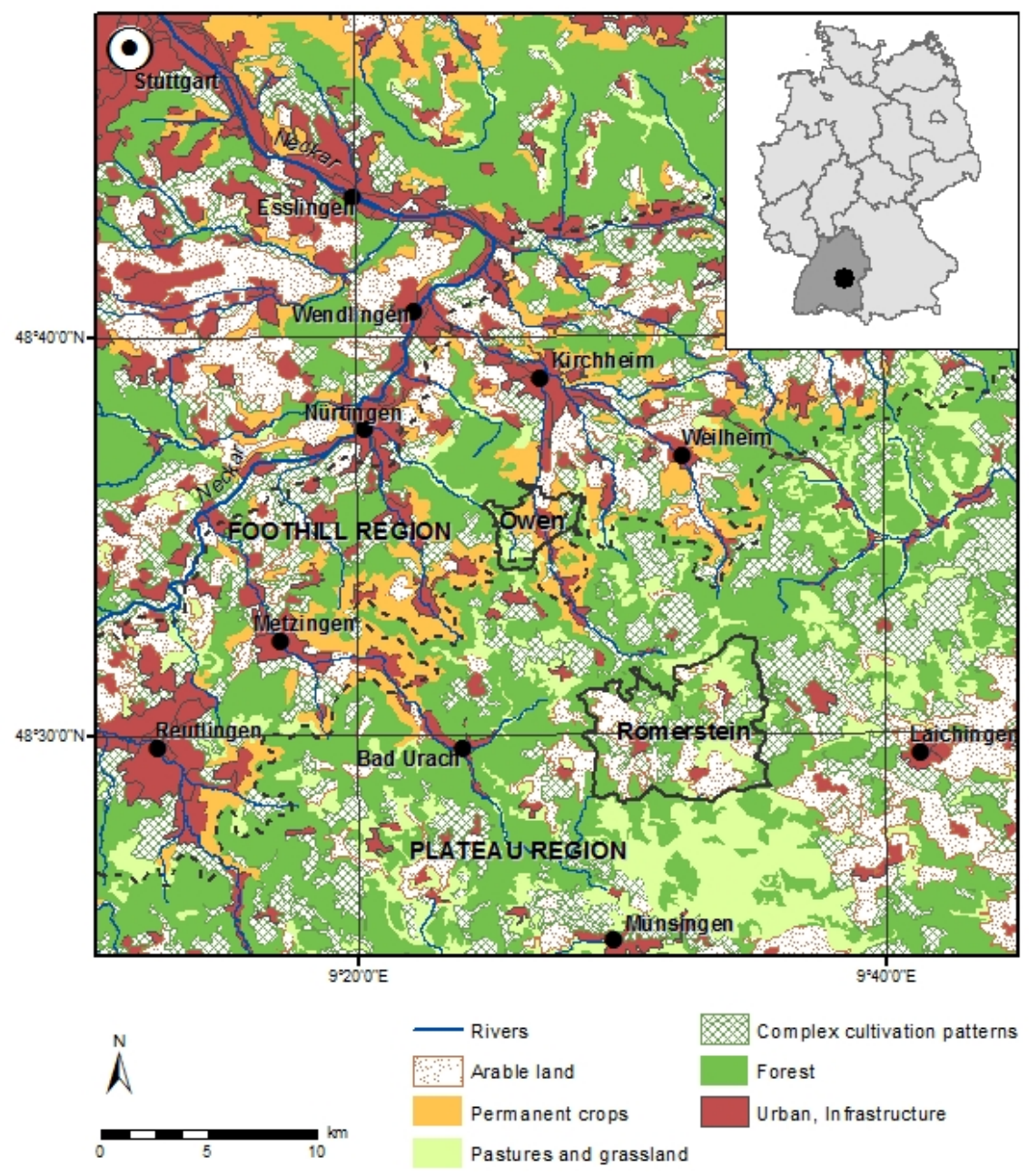

differences in population densities (ranging roughly between 80 and 500 persons per $\mathrm{km}^{2}$ ) and socioeconomic characteristics between the foothills and the plateau areas. In the foothills region, population growth that started in the postWorld War II period has been particularly pronounced. In the plateau region, settling density is significantly lower than in the foothill area. Compared to the German average, unemployment rates are very low in the Swabian Alb region, with people mainly occupied in the secondary and tertiary sectors. Less than $1 \%$ of the population receives its full income from the agricultural sector. In general, rural-urban linkages are intensively developed in terms of both people commuting from the area, especially to the Stuttgart region, and visitors coming to the Swabian Alb for tourism and recreation.

\section{Long-term and short-term landscape history}

The Swabian Alb constitutes a complex cultural landscape in which social, economic, and environmental components are closely interwoven (Farina 2000). The area has been settled permanently since the Neolithic age, but the first significant landscape transformations (e.g., reduction of forest cover and building of infrastructure and settlements) were undertaken by the Celts starting in the $8^{\text {th }}$ century BC (see Fig. 2). Under the Roman reign, urbanization was increased and agricultural land use intensified. Today's settlement structure and the distribution of open and forested lands go back to inland colonization of the Alemanni during the Middle Ages $\left(5^{\text {th }}\right.$ $11^{\text {th }}$ centuries AD). Population growth triggered the shift from an alternate arable field-pasture system to a 3-field rotation crop system, which dominated landscape development from the early Middle Ages through the $19^{\text {th }}$ century (Poschlod and WallisDeVries 2002). During those times, sovereigns established transhumant grazing systems of large flocks of sheep and other livestock, thereby keeping abandoned fields open and shaping calcareous grass- and heathlands. Viticulture 
Fig. 2. Major eras and events in the land-use history of the Swabian Alb.

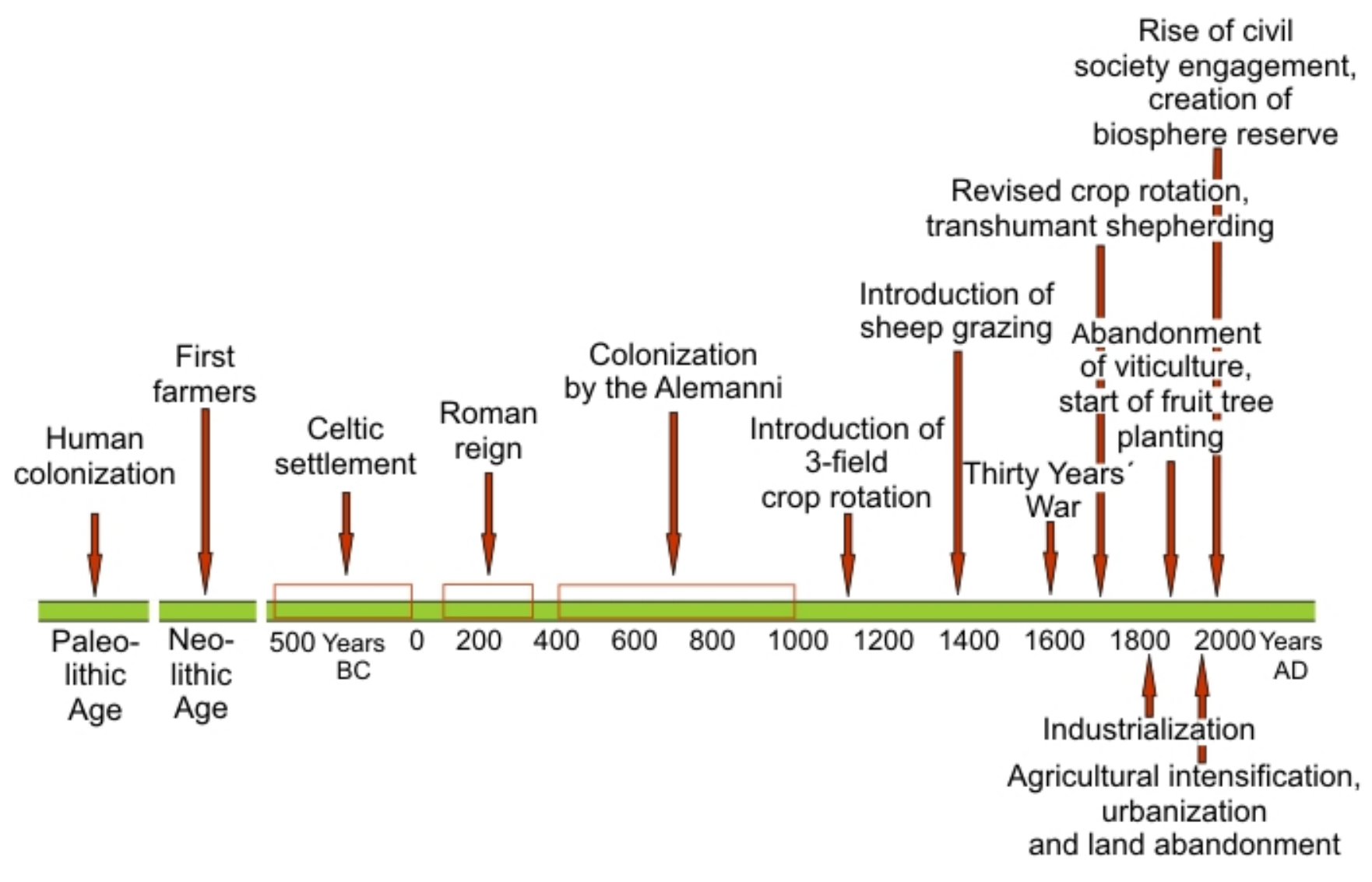

had been practiced on a large scale in the foothill areas of the Swabian Alb since the early Middle Ages, but was abandoned because of the invasion of grape phylloxera and rising competition with wine producers from the Rhine area in the $19^{\text {th }}$ century. In the $18^{\text {th }}$ and $19^{\text {th }}$ centuries, sovereigns of the area commenced plantation of fruit trees around villages, but also on spare lands and grasslands (Herzog 1998).

During the $19^{\text {th }}$ century, industrialization became important in shaping the cultural landscape (Regierungspräsidium Tübingen 2007). For example, the building of railways and new roads opened up the Alb plateau for fodder and food imports as well as for recreation (Beinlich and Manderbach 1995). With booming industry in the nearby metropolitan area in the $20^{\text {th }}$ century, more and more farmers found employment there, and agricultural activity generally decreased because of its diminishing profitability. Consequently, particularly in the second half of the $20^{\text {th }}$ century, the number of farms declined heavily but mean farm sizes increased significantly. Together, these developments led to an abandonment of marginal agricultural land and its subsequent conversion to forests, and the remaining farmland has been continuously intensified
(Bieling et al.2013). A dramatic loss of highly valued farmland plant and animal species that were once abundant in the calcareous grass- and heathlands and orchard meadows triggered the establishment of protected areas and the implementation of agri-environmental measures in the second half of the $20^{\text {th }}$ century. Also, a multitude of associations, communities, initiatives, and enterprises have become active in promoting local regional development, finally leading to the area's designation as a biosphere reserve by UNESCO in 2009.

For the purpose of this scenario exercise, we selected two municipalities (Römerstein and Owen) in the Swabian Alb Biosphere Reserve (Fig. 1). The municipality of Römerstein (Fig. 3) represents the more rural Alb plateau (85 inhabitants/ $\mathrm{km}^{2}$ ) whereas Owen (Fig. 4) was deemed typical for the densely populated Swabian Alb foothills (355 inhabitants/ $\mathrm{km}^{2}$ ). Both municipalities exhibit traditional, region-specific landscape elements (Römerstein: calcareous grassland; Owen: high nature value orchard meadows) as well as ubiquitous forms of land use (Römerstein: intensively used agricultural land; Owen: urban sprawl). 
Fig. 3. Current landscape character in the Römerstein area. Source: Römerstein municipal administration.

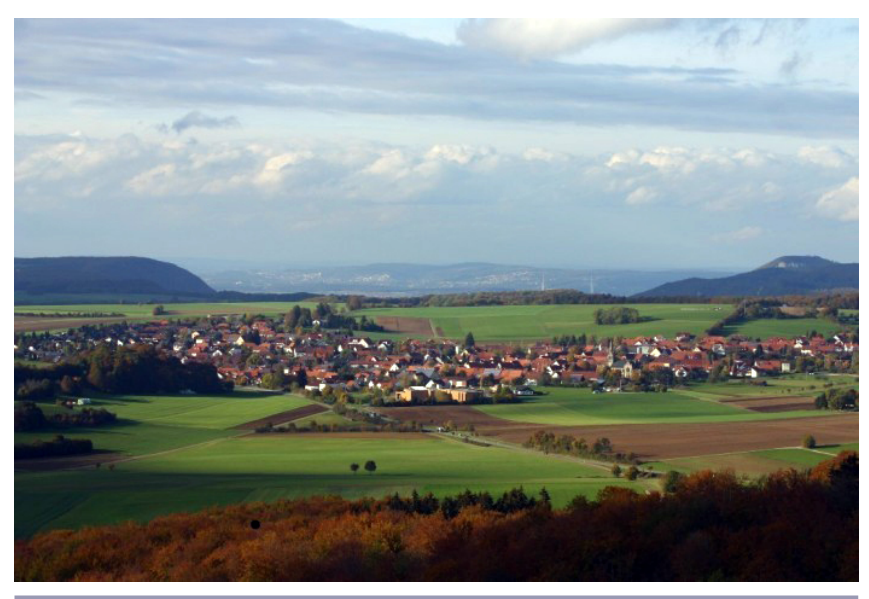

Fig. 4. Current landscape character in the Owen area. Source: F. Wolff

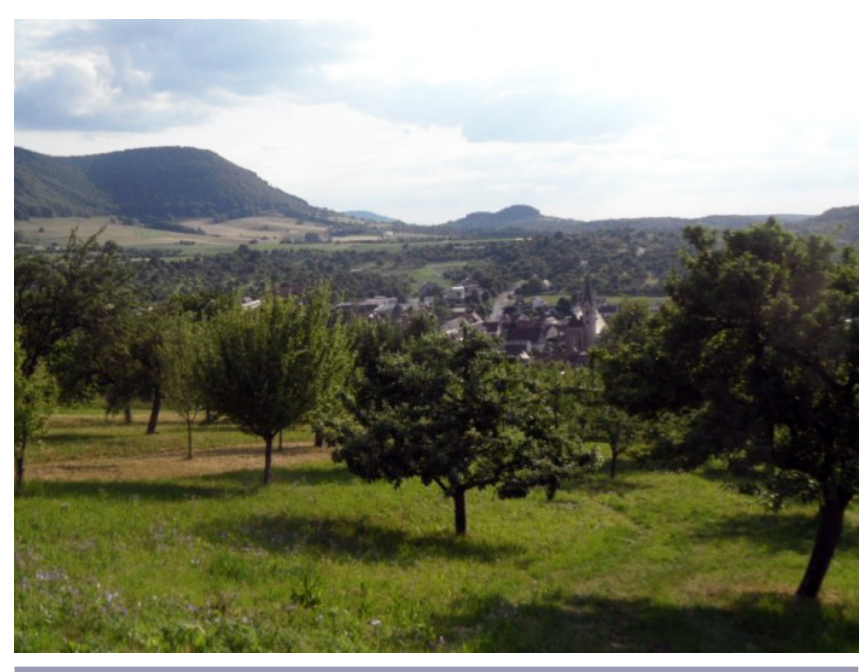

\section{METHODS}

\section{Overall approach}

We chose a participatory approach of exploratory scenario development to conceive and describe a range of possible future outcomes for this area (negative or positive), taking into account past developments, current trends, and uncertainties (Lynam et al. 2007). The scenario development process was embedded into a larger interdisciplinary research project that investigates land-use change and ecosystem services provision in the Swabian Alb Biosphere Reserve (Bieling and Plieninger 2012, Plieninger 2012, Bieling et al. 2013, Schaich and Plieninger 2013). The process began with a 3-d preparatory meeting in which all researchers took part, led by an experienced scenario trainer. Here, the key steps of the scenario process were defined as: (a) identifying the driving forces influencing the communities, (b) building contrasting narratives about potential alternative futures, (c) refining the narratives, (d) discussing scenario impacts on local communities, and (e) developing management strategies (Evans et al. 2006, 2008). Our approach was inspired by preceding local-scale scenario development in the context of the Millennium Ecosystem Assessment (e.g., Peterson et al. 2003, Palomo et al. 2011).

For this scenario exercise, local actors were invited to develop scenarios around the following question: "What will the local cultural landscape look like in the yr 2040 in response to global and local land use trends?" The scenario process comprised background research on local human and ecological histories through a literature review and making use of our 3-yr research activities in the Swabian Alb Biosphere Reserve as well as a series of workshops with local actors (Fig. 5). Following an analysis of stakeholders in the area, we targeted a variety of local-level landscape users, ranging from farmers and shepherds to entrepreneurs, environmentalists, hobby gardeners, and local policy makers, as potential participants in the scenario process. Participants were invited to participate in workshops through local newspapers, parish newsletters, or personal communication, such as by phone or mail. Participants in the workshops were composed of mayors, members of town councils, farmers, members of conservation NGOs and of a walking club, the chair of the local business association, a shepherd, a gardener, and interested citizens. One or two media representatives observed parts of each workshop and reported on the activities in local newspapers. The researchers planned, organized, structured, and documented all activities related to the workshops. As such,

Fig. 5. Key steps, methods, outcomes, and conclusions of the scenario process.
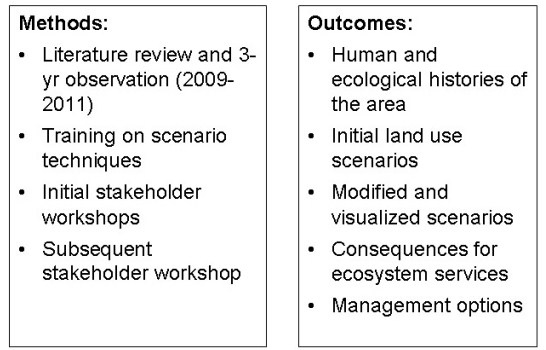

Conclusions:

- Future drivers of landscape change

- Possibilities and limitations of local landscape conservation and development 
the workshops were prestructured regarding their form and central aims, but remained completely open for the participants regarding content. This primarily means that no scenarios, drivers, or events were predetermined by the researchers. Methods applied to integrate the participants' contributions included plenary and group discussions as well as individual ranking and assessment exercises (compare Palomo et al. 2011).

\section{Initial workshops: building plausible scenarios}

The participatory process was divided into two phases. In the first phase (spring 2011), we held 1-d workshops in both Römerstein (13 participants) and Owen (seven participants), producing two detailed landscape development scenarios for each municipality. The workshops were carried out separately in each location, but followed exactly the same procedure. To get the workshops going, the researchers provided an introduction to the scenario technique and an overview of past landscape changes in the area, based on statistical data, maps, and aerial photographs. The participants then prepared a list of relevant actors and driving forces that they perceived as potentially determining for future local landscape change. In subsequent discussion, the participants agreed on two driving forces which they deemed most important with regard to future change. Displayed as two axes, each ranging from low/weak to high/strong, the possible combinations of these two main driving forces resulted in four possible scenarios. In each municipality, the participants then selected two possible scenarios which they considered most likely and relevant. The participants were divided into two groups, each elaborating a detailed storyline and description of future situations and events in 10-yr steps up to the yr 2040 for only one of the two scenarios, with the other group doing the other scenario. The workshops closed with a presentation and discussion of these detailed scenarios.

\section{Subsequent workshop: refining scenarios, discussing consequences for ecosystem services and quality of life, and exploring management options}

In the second phase (spring 2012), 14 participants from Römerstein and Owen jointly identified and substantiated management options for guiding landscape change at a halfday workshop. The participants ranked 27 different ecosystem services in the region according to their importance and assessed their vulnerability with regard to future landscape development. Potential development of eight various dimensions of local quality of life and their linkages to changes in ecosystem services provision were also considered. These dimensions were: infrastructure, housing, employment, environment, income, family, health, and social relations. The scenarios developed in the initial workshops served as a basis for more specifically investigating options for landscape management at the local scale. The researchers presented the scenarios and briefly reflected on their possible effects on ecosystem service provision. For this, the four detailed scenarios from the first workshops (two from each) were taken up by the research group. In preparation for the workshop of the second phase, our research group illustrated the most characteristic aspects of each scenario in the form of an image and a poster with fictive future newspaper headlines and brief articles. Such types of visualization are common in participatory scenario exercises to characterize differences between scenarios (c.f. Peterson et al. 2003, Palomo et al. 2011). The aim of our illustrations, presented before the elaboration of the scenario outcomes, was to recapitulate the outcomes of the initial workshops and to initiate a lively discussion about the envisioned impacts of each scenario on ecosystem services, and potential beneficiaries and losers in terms of resources, power, and influence on land-use decisions. This discussion provided the basis for the main goal of this workshop: identifying and discussing possible management options at the local scale for the four ecosystem services that were identified as most important and most vulnerable during the preceding evaluations. The participants formulated ideas for possible action, detailed which people or institutions needed to act, and reflected on possible side effects and trade-offs of the proposed measures. The workshop closed with the presentation and joint discussion of the results of each subgroup.

The workshops were tape-recorded, and key results were captured in the form of posters and documented by photographs. The researchers wrote reports on the scenarios developed in the first workshops, which were then reviewed by the respective participants.

\section{RESULTS}

Changes in quality of life and landscape linkages

When asked to evaluate how eight different aspects of their quality of life had changed over the past three decades in their municipalities, participants identified diverging trends (Fig. 6). Quality of life related to work, income, infrastructure, environment, and housing was mainly seen as having increased. A majority considered health an issue with neither negative nor positive tendencies. In turn, most participants stated that social relations had decreased over the past decades, but the answers of some respondents diverged from this view. When asked which aspects of their quality of life they considered as being closely linked to their local cultural landscapes, respondents most frequently cited environmental aspects (32\% of entries), followed by housing (24\%), and health $(21 \%)$. Family, infrastructure, and income were also seen as connected to some extent to local cultural landscapes, whereas none of the participants mentioned the particular importance of local landscapes for work or social relations. 
Fig. 6. Perceived changes in quality of life aspects over the past $50 \mathrm{yrs}$ (percentage of all answers).

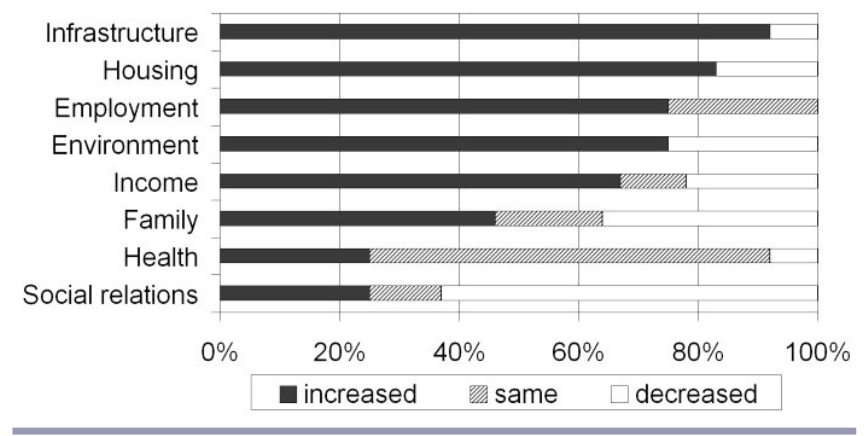

Use and vulnerability of ecosystem services

Of the 27 landscape-scale ecosystem services that the researchers presented to the participants, 11 were cultural, 10 were provisioning, and six were regulating services. The highest importance values (four to six entries) were assigned to regulating and provisioning services. The highest values for vulnerability (five to seven entries) were assigned to provisioning and cultural services. In Fig. 7, ecosystem services are sorted by importance (x-axis) and vulnerability (y-axis), and the most critical services, defined as being of high importance and vulnerability values, are shown in the upper right quadrant. High importance and high vulnerability values were assigned to shepherding and fruit production in orchard meadows. Both of these are provisioning services, but include important cultural components. Shepherding on the Swabian Alb is not only practiced as a means of meat production, but is also related to the maintenance of an aesthetically pleasing landscape. Orchard meadows not only provide dessert fruits and juice (that could actually be produced more cheaply under more intensified systems), but are likewise related to recreation, social relations, aesthetics, and sense of place. High importance values were also assigned to soil fertility, biodiversity conservation, production of food and timber for local consumption, and the landscape as a basis for sense of place. Energy crop production, groundwater protection, spiritual and religious values, and food and fodder production for distant markets were ranked as less important by participants.

\section{Drivers of change}

Following intense discussion, participants identified changes in local consumption patterns and the types and intensity of state regulation or intervention as the two most important drivers of future landscape development in the 2011 Römerstein workshop (Fig. 8). Consequently, the first scenario narrative, entitled "less is more," suggests an increasing consumer preference toward high-quality and regionalized agricultural produce on the one hand, and a preservation of the status quo of state support programs for rural development as well as stricter regulation of production processes in rural areas on the other (Table 1). In turn, the "AlbGAU" (GAU = German abbreviation for "worst-case scenario") scenario posits that future consumers would aim to pay as little as possible for food, with no interest in quality or origin. At the same time, the state would, by and large, cede all relevant support programs and regulations, thus leaving the agricultural and food sector to "free-market" forces. The participants of the Owen workshop considered changes in energy demand and appreciation of cultural landscapes among the local population to be the main driving forces. The "spirit of invention" scenario is characterized by high and continuously increasing energy demand, yet accompanied by a high appreciation of distinct cultural landscapes. The second scenario, termed "energy silo," also begins with the assumption that energy demand would increase substantially, but expects that appreciation of the cultural landscape would decrease. Each scenario is depicted in Fig. 9.

\section{Land-use development and impacts on biodiversity and ecosystem services}

The "less is more" scenario envisions a landscape pattern characterized by small-scale, family-run, conservationfriendly, and often organic forms of farming. Local agriculture uses low energy and material inputs, but is highly labor intensive. A large variety of crop and animal production systems, including traditional shepherding for landscape management purposes, are being introduced or revitalized. Diverse energy crops, mainly short-rotation woody plants, become integral components of agriculture. Along with successful efforts to seriously reduce levels of energy consumption, self-sufficient energy generation for the village is expected. Local food processing and the production of handicrafts are increasing significantly.

In the "AlbGAU" scenario, the landscape experiences drastic changes. Given stepwise abolishment of agricultural state support, dairy and sheep farming cease to exist, along with all other forms of local food and feed production. Much of the remaining farmland is encroached by shrubs, and forests expand substantially in the course of large-scale land abandonment. Intensively managed energy crops, the only remaining viable form of agriculture, dominate the remaining farmland. Thus, land use is polarized, with intensive biomass production on one side, and expanding forests on the other. The biosphere reserve shuts down when public budgets are cut; at the same time, the Swabian Alb loses its tradition as a tourism area. Population decreases in many parts of the plateau area.

Given an increased interest in regional products and in the restoration of locally distinct cultural landscapes in the "spirit of invention" scenario, once-abandoned orchard meadows and 
Fig. 7. Perceived importance and vulnerability of ecosystem services provided by local cultural landscapes, over the discussed time period. Black indicates predominantly provisioning services, green represents regulating services, and blue represents cultural services (modified from Palomo et al. 2011).

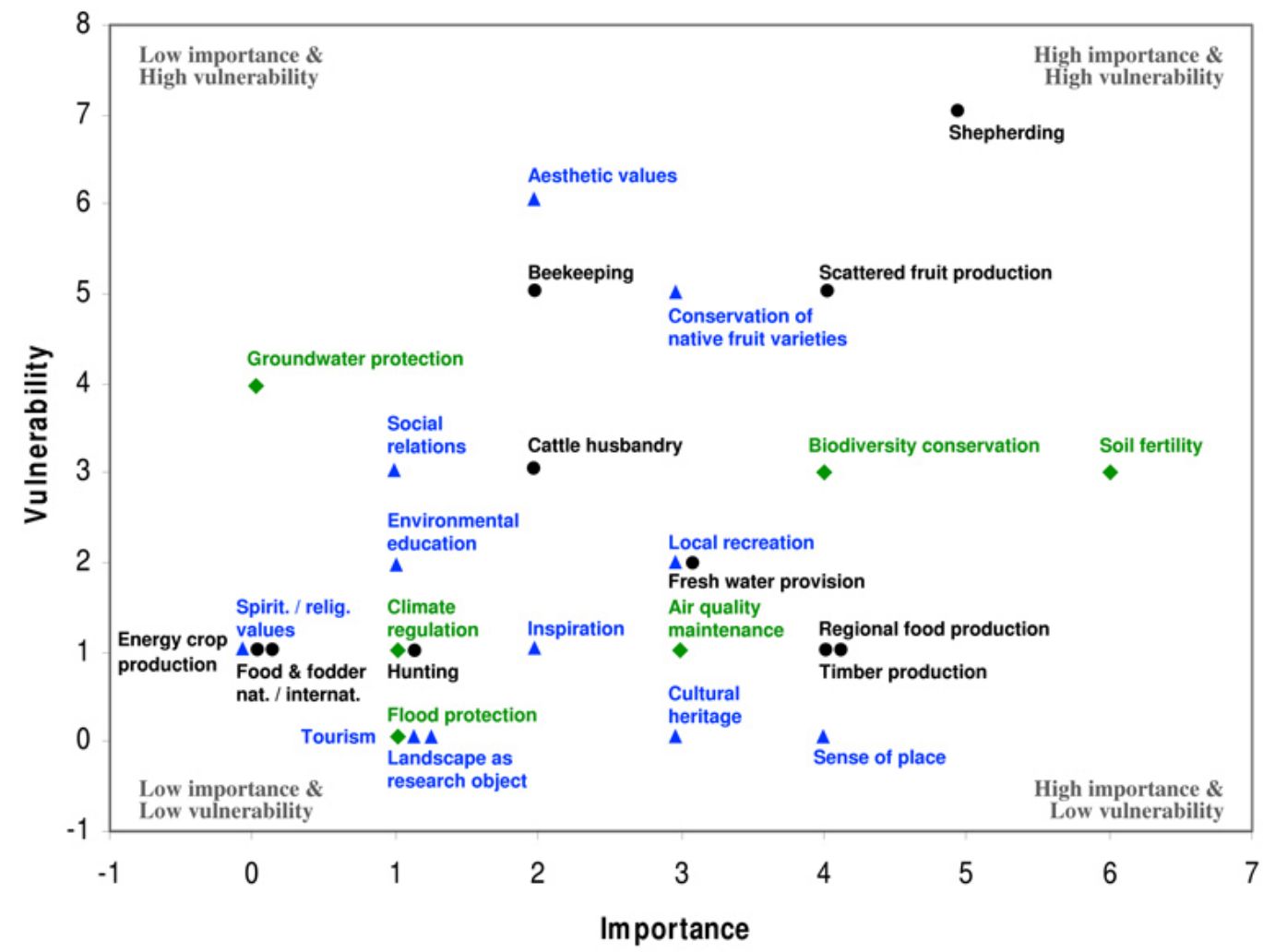

Fig. 8. Key drivers of future landscape development in the four scenarios.

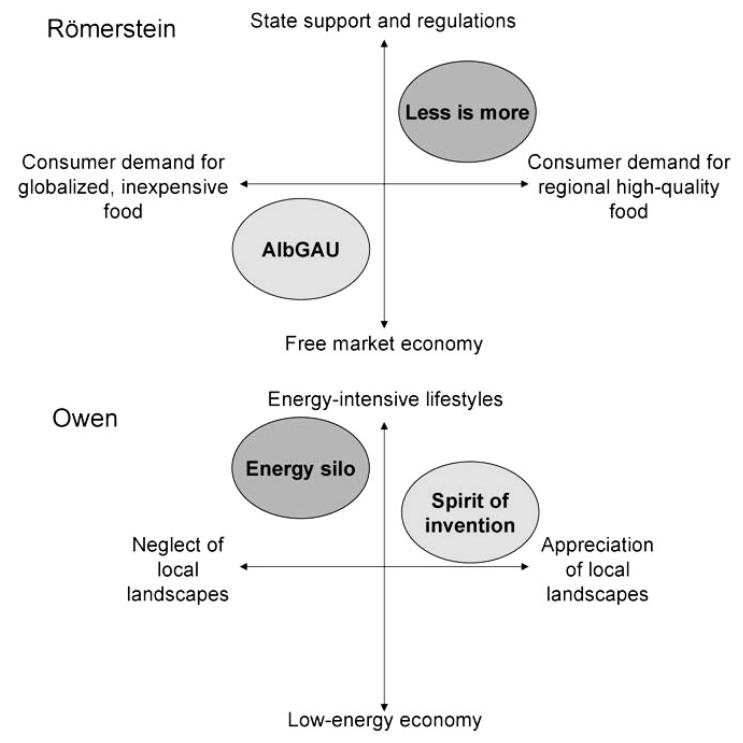

other agricultural lands are being reactivated. Local food production is strong but follows intensive production pathways. Increased temperatures also allow for new crops, such as grape vines. Energy crop production, wind farms, and solar parks spread out across the landscape. This scenario is named after the important inventions in regenerative power engineering it envisages, which give rise to a job boom in the renewable energy sector, followed by intensive in-migration of employees. To minimize subsequent land consumption, local ordinances ensure that settlements become denser, are planned to reduce sprawl, and increasingly place traffic infrastructure underground.

In the "energy silo" scenario, local lifestyles are highly energy intensive, and the landscape is widely used for the industrial production of energy crops. Furthermore, large wind and solar parks are installed, accompanied by a boost in the numbers of industrial and commercial parks. Local industry creates jobs in large numbers, in particular in the area of decentralized power-plant installation and maintenance. Regional food production is reduced to a minimum. With the landscape becoming aesthetically impoverished, people turn from nature-based to indoor recreational activities. The technification of local cultural landscapes provokes strong 
Table 1. Key features of the scenario narratives.

\begin{tabular}{lllll}
\hline \hline Scenario & Less is more & AlbGAU & Spirit of invention & Energy silo \\
\hline General & Societal demand for high- & Preference for low-cost & Increase in energy demand; & Strong increase in energy \\
description & quality and local food; & food; reduction of state & appreciation of local cultural demand; decrease of \\
& substantial state support for & support programs and & landscapes & appreciation of local cultural \\
& rural development & regulations ("free market") & & landscape
\end{tabular}

Population Stable, little in- or outmigration
Severe outmigration, particularly of young people
Substantial inmigration (in particular, engineers)
Mixed patterns of in- and outmigration
Landscape

Small-scale mix of grassland, arable land, shortrotation forests, preservation of mosaic landscape

Employment

Increase (agriculture, including processing; tourism)

Local identity Diverse and aesthetically appealing landscapes (re) create genius loci for regional identity

Tourism Increase in farm-related tourism

Agriculture Mix of small-scale and
diverse family farming and
energy-crop farming productive sites and focused "modern" food production,
Agriculture reduced to most Mix of "traditional" and on industrialized energycrop farming

Monocultures of energy crops (maize, short-rotation forests) on large plots; encroachment of shrublands and forests

Substantial loss (agriculture, Increase (energy tourism)

technology, development)

Loss of landscape-related cultural services and social capital

Substantial decrease

Substantial increase including fruit, vegetables, viticulture (given climatic changes), and biomass production
Farming simplified to intensive energy-crop farming at large scale; in 2030s, return to slightly more integrated agriculture concern in the population, and energy infrastructures are repeatedly damaged by radical individuals. However, the negative effects of the changing landscape trigger some societal changes and counter-developments. Thus, the landscape of the yr 2040 is characterized by a slightly more integrated land-use mosaic, but the character of a technified agricultural landscape continues to prevail.

Table 2 summarizes key impacts on biodiversity and ecosystem services given each of these scenarios. Biodiversity, regulating, cultural, and food-provisioning services decreased in the "AlbGAU" and "energy silo" scenarios, whereas they remained constant or improved in the "less is more" and "spirit of invention" scenarios. An increased use of energy-provisioning services from local landscapes was found across all scenarios. The "less is more" scenario generated the greatest number of positive impacts on the whole set of services.

\section{Beneficiaries and losers}

For each scenario, participants identified (partly overlapping) actor groups that would benefit or lose from the developments in the respective scenarios. These groups were the local population, tourism, nature conservation, agriculture, and the energy sector. With respect to the "less is more" scenario, it was assumed that the local population, tourism, and agriculture would profit substantially, whereas nature conservation and energy production would still gain in the process. In turn, a 
Fig. 9. Visualization of the "less is more," "AlbGAU," "spirit of invention," and "energy silo" scenarios (moving from top left to bottom right). Design: A. Rodríguez García.

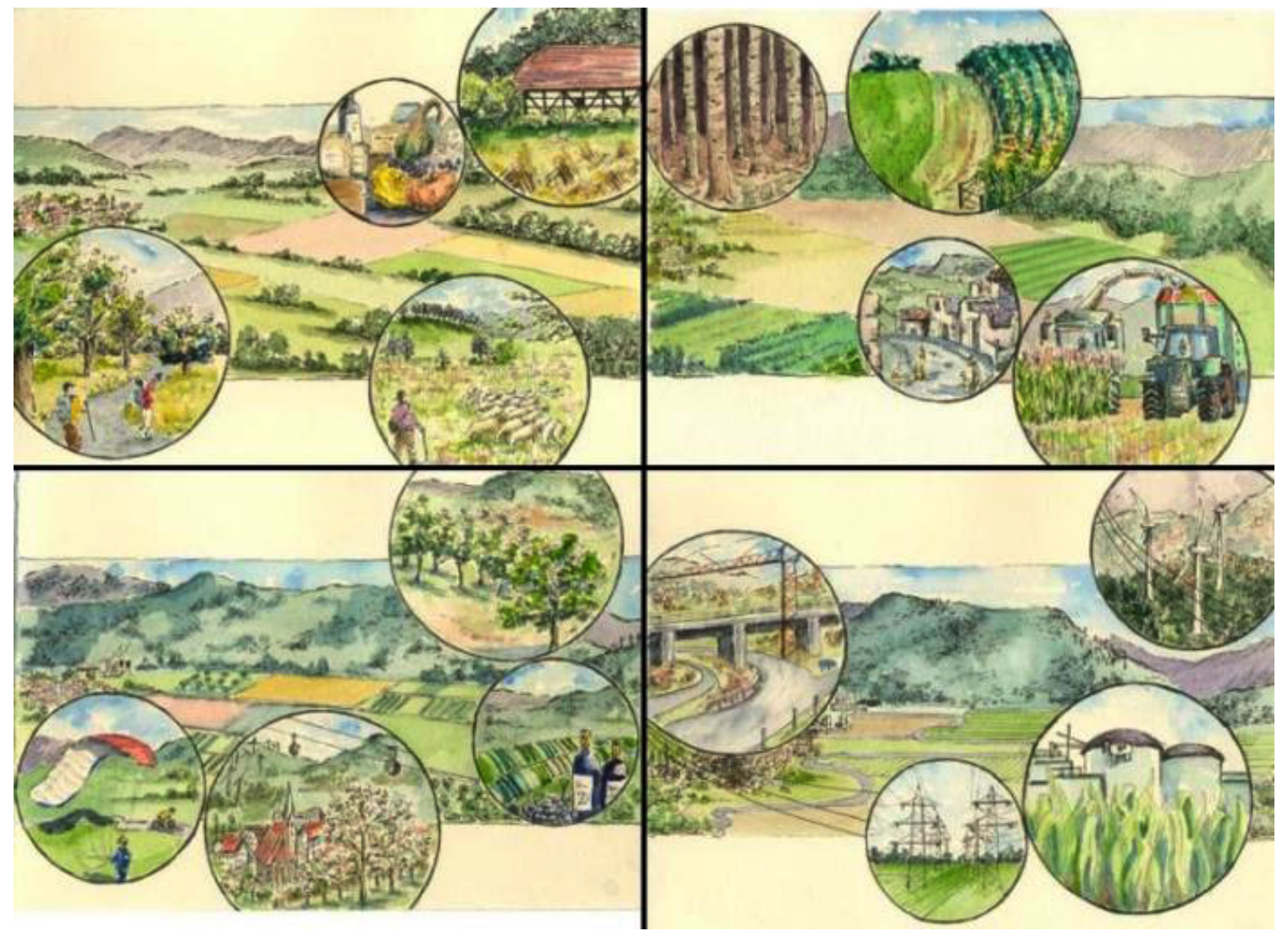

Table 2. Impacts of scenarios on biodiversity and ecosystem services.

\begin{tabular}{lcccc}
\hline \hline Scenario & Less is more & AlbGAU & $\begin{array}{c}\text { Spirit of } \\
\text { invention }\end{array}$ & Energy silo \\
\hline $\begin{array}{l}\text { Biodiversity } \\
\text { Provisioning } \\
\text { services: }\end{array}$ & $\uparrow \uparrow$ & $\uparrow$ & $\leftrightarrow$ & $\downarrow \downarrow$ \\
food & & $\downarrow$ & $\uparrow$ & $\downarrow$ \\
$\begin{array}{l}\text { Provisioning } \\
\text { services: }\end{array}$ & $\uparrow$ & $\uparrow \uparrow$ & $\uparrow$ & $\uparrow \uparrow$ \\
$\begin{array}{l}\text { energy } \\
\text { Regulating }\end{array}$ & $\uparrow$ & & & \\
$\begin{array}{l}\text { services } \\
\text { Cultural } \\
\text { services }\end{array}$ & $\uparrow \uparrow$ & & $\leftrightarrow$ & $\downarrow \downarrow$ \\
$\begin{array}{l}\uparrow=\text { slight positive trend, } \\
\downarrow=\text { slight negative trend, }\end{array}$ & $\uparrow \uparrow=$ strong positive trend, \\
$\leftrightarrow \downarrow=$ strong negative trend, & \\
$\leftrightarrow=$ no change & & &
\end{tabular}

rather bleak assessment was made for the "AlbGAU" scenario. Here, the local population, tourism, and agriculture would suffer greatly, but the energy sector would profit significantly; meanwhile, no overall changes were expected for nature conservation. A similar picture was drawn for the "energy silo" scenario, with the only difference that the local population and nature conservation would suffer only slightly. In the "spirit of invention" scenario, only agriculture would be somewhat negatively affected. All other actor groups would benefit substantially, or, in the case of tourism, at least to some extent.

\section{Local-scale management options}

Participants further selected four ecosystem services as being particularly critical. These critical items were identified to be pollinating insects, traditional orchards with local varieties of fruit trees, sheep grazing on high nature value grass- and heathlands, and soil fertility. All of these elements require management forms conducive to maintaining or generating them, and allow for as well as require local action. In the discussion, a range of management options was subsequently identified, and potential side effects of fostering these services were explored (Table 3). A common thread throughout the discussion was the development of suitable incentive schemes, usually achieved by coupling provision of specific landscape 
Table 3. Management options to particular threats and potential side effects, as proposed by local actors.

\begin{tabular}{lll}
\hline \hline Threat & Management options & Side effects \\
\hline Decline in pollinating & $\begin{array}{l}\text { Improving insects' food resources through increased wild-flower } \\
\text { abundance and diversity }\end{array}$ & $\ldots$ \\
insects & Minimized use of pesticides and fertilizers & \\
& $\begin{array}{l}\text { Investment in environmental education and farm-extension } \\
\text { services }\end{array}$
\end{tabular}

\begin{abstract}
Abandonment of orchard Energetic use of the understory and byproducts of juice meadows production

Mixed cultivation of fruit trees and energy crops

Production of biofuels based on alcohol
\end{abstract}

Unprofitability of sheep

grazing on grass- and

heathlands

Declining soil fertility
Investment in environmental education Improved commercialization of sheep products Strengthening of regional marketing and tourism

Promotion of low-intensity and organic farming Increased use of compost

Regular soil inspections
Lower fruit and smaller hay yields

Conflicts with industrial livestock farming, potential browsing damage to forests

Yield reductions, increased food prices, potential lack of adoption by farmers features with the marketing of locally produced high-quality food.

\section{DISCUSSION}

\section{Drivers and outcomes of alternative landscape futures} Our scenario exercise began with the question of how global and local drivers influence cultural landscape development in the context of a well-developed rural area in Central Europe. Compared with previous scenario exercises performed in more marginalized areas of Europe (e.g., Van Berkel et al. 2011), some of the outcomes were surprisingly positive. Our participants perceived substantial improvements in most aspects of their quality of life over the past three decades, and recognized several links between their quality of life and the state of local landscapes. Participants also identified important local-scale ecosystem services, such as fruit production in orchard meadows, regional food production, and conservation of native fruit and crop varieties. Similar to elsewhere in Europe (Pereira et al. 2005), material aspects of quality of life were detached from trends in local ecosystem services provision. However, the cultural aspects of landscapes were strongly appreciated. Also, it was felt that energy-provisioning services from local landscapes would be clearly needed in future. The discussion about the societal values of cultural landscapes showed that most participants felt uncomfortable with a narrow understanding of ecosystem services. It became clear that they do not feel themselves to be part of an "ecosystem," which, in the German language, has the often negatively construed connotation of "environmentalism." At the same time, the participants found a purely economic concept of "services" to be problematic, as it touched only one of many of their links to nature (compare Chan et al. 2012). Further, the strict separation between services provided by ecosystems and services provided by people managing ecosystems appeared artificial to many participants, as the area's cultural landscapes were perceived as coupled and intensively managed social-ecological systems (compare Schaich et al. 2010). However, when stressing "landscapes" rather than "ecosystems," and "values" rather than "services," the ecosystem-services approach proved useful as a unifying framework for stakeholder interaction (Termorshuizen and Opdam 2009).

When determining the most important drivers of landscape change, both the Römerstein and Owen workshops selected one global-level driver each (state support and regulation vs. free-market economy; energy-intensive lifestyles vs. lowenergy economy) and one local-level driver (high vs. low consumer demand for local food; high vs. low appreciation for local cultural landscapes). Scenario exercises in both villages produced two narratives, each with one preferable and one more negative scenario. Conspicuously, development of local agriculture, and, in particular, energy cropping (compare Plieninger et al. 2006) received much attention, even among nonfarmer participants. Local energy supply from energy crops, wind farms, solar parks and the like were part of all scenarios, with two calling for large-scale renewable energy supply methods ("AlbGAU," "energy silo"), whereas the others ("less is more," "spirit of invention") stressed their 
integration into a multifunctional landscape. Perceived risks, all leading to a loss of appreciated landscape features, included continuing land consumption for expanding settlement and traffic, abandonment of traditional land uses, and intensification and standardization of agricultural uses. These outcomes are similar to other landscape-scenario exercises in European mountain areas (Soliva et al. 2008). Although with different foci, these also identified agricultural liberalization, nature conservation, land abandonment, recreation/tourism/ residential expansion, renewable energy supply, and multifunctionality as important trends. Participants developed a set of ideas for landscape-scale action to foster locally important, but vulnerable, ecosystem services. These may help to identify and guide decisions, policies, and other instruments that could lead to desired future landscapes (Loupa Ramos 2010). However, the discussions at the workshops confirmed that local stakeholders have disparate visions for cultural landscapes (Lindborg et al. 2009) and each possible future produces beneficiaries and losers.

The outcomes of the scenario process can be related to the discussion on the overarching effects of globalization. Globalization involves aspects of increasing speed of interactions, intensification and multiplication of global linkages, and stretching human activities to the global scale (Young et al. 2006). Its main economic manifestations are market liberalization and "free trade" (O'Brien and Leichenko $20002003)$. With regard to governance, globalization supports the displacement of states' authority upward to international organizations, downward to subnational authorities and outward to semi-public and private bodies (Pierre and Peters 2000). Globalization phenomena, driven by technological developments as well as deregulating policies (neoliberalism), may shape landscapes. This occurs through the spread of technology, investment in land, information flows, transport infrastructures, migration patterns and, in particular, increased international commerce and trade (Primdahl and Swaffield 2010). In this context, the acknowledgement of both local and supra-regional drivers of change in the Swabian Alb (as demonstrated by the groups' choice of drivers) provides further evidence that interconnectedness among variables at different scales has become a highly influential phenomenon for landscape change (Seto et al. 2012).

However, as our study shows, globalization as it is perceived by local actors does not necessarily mean that landscapes need to be increasingly shaped by events and decisions taken in distant locations (compare Reenberg et al. 2010). Scenario discussions revealed that our participants do not feel helpless against outside landscape drivers. Many of them are working in enterprises that have profited from economic globalization, but nonetheless stressed the local potential to influence higher level drivers. This became particularly clear in the discussion on how to cope with the shift toward renewable energy supply, which is a global trend. Here, the "less is more" and "spirit of invention" scenarios stressed the potential of local communities to influence the course and specific arrangements of renewable energy generation in cultural landscapes. This finding is in line with the observation that globalization is frequently accompanied by decentralization (for example, when driven by neoliberalization) and thus can shift responsibilities and decision-making processes to a more local level of resource management (Engel and Palmer 2011). On the other hand, the decline of local diversity through the mixing and homogenization, most prominently of biological and cultural diversity, as well as of management practices, has been described as a major impact of globalized land use (Young et al. 2006, Gómez-Baggethun et al. 2010). The participants of the scenario exercise in the Swabian Alb were clearly aware of these risks. However, they developed various ideas on how to halt or transform these trajectories through local-scale activities, e.g., by fostering and developing local orchards. It remains to be seen whether these activities would indeed effectively alter landscape dynamics driven by globalization.

\section{Insights for scenario process design}

Our study applied a narrative, open-scenario approach based on the participation of local actors. This process revealed several benefits. The workshops provided rich insights, both for the researchers and the local actors, into local views and perceptions, for instance as well as regarding developments beyond the Swabian Alb region. From a scientific point of view, this resulted in a differentiated perspective on the "realworld" situation in the investigation area and the opportunity to verify more general scientific knowledge with experiencedriven and localized knowledge from key actors. For the local participants, a main benefit was the opportunity to enhance their capacities to successfully deal with landscape change and the resulting impacts on human quality of life. Several persons stated that they felt better prepared for future developments and now saw more possibilities for being proactive instead of passively responding to changes. Some participants highlighted the value of envisioning landscape futures as a prerequisite to developing suitable landscape management and policy options, although "internal" discussions among participants seemed to a more useful basis for this than the visualizations that our "external" research group had provided. We also faced some challenges in employing the open participatory scenario approach. It is well known that participant configuration critically determines the outcomes of scenario exercises (Pahl-Wostl 2008, Henrichs et al. 2010). However, similar to previous experiences (Loibl and Walz 2010, Albert et al. 2012), the number of participants at the three workshops was relatively small, and some specific sectors were not represented (e.g., forestry). To achieve full coverage of local perspectives, a higher number of participants, combined with a stricter admission process, would have been desirable. Reducing the duration of the initial 
workshops to a few hours would possibly have succeeded in drawing more participants. However, a shorter time span and a higher number of participants would also have likely complicated facilitation and would not have allowed for the intensive, creative, and open character that was crucial for the workshops' success.

\section{Validity and reliability of the scenarios}

In the development of scenario narratives, the classic research paradigm of "validity" and "reliability" of results needs to be extended to more adequately reflect the nature and objectives of the qualitative research processes (e.g., Mayring 2002). Such "extended" criteria comprise: (1) "credibility" (in place of internal validity), (2) "transferability" (in place of external validity), (3) "dependability" (replacing reliability), and (4) "confirmability" (instead of objectivity; Lincoln and Guba 1985). Our experiences indicate that there may be a trade-off between credibility and transferability on the one hand, and dependability on the other. Confirmability can be addressed through quality controls.

The "credibility" criterion requires that the results of qualitative research are credible from the perspective of the participants in the research (as "experts" of their everyday world). The generally positive feedback we gained from workshop participants with regard to the scenario method, the process and its policy relevance can be interpreted as evidence of such credibility.

"Transferability" describes the degree to which the results of qualitative research can be generalized or transferred to other contexts. A caveat with the transferability of our scenarios is that our participants represented a limited segment of the community. Yet, the fact that participants in the different scenario teams identified rather similar drivers of landscape change indicates that there is a supra-individual element to the perception of landscape change that can also bridge the differences between the selected villages.

"Dependability" requires that findings are consistent and can be repeated, emphasizing the need to account for changes in the contexts within which research takes place. When developing participatory scenarios, dependability suffers from the fact that scenarios, to a certain extent, are a product of the "guided fantasy" of the individual workshop participants' creativity and the group dynamics unfolding among them. Also, individual perspectives are time-sensitive and may be influenced by short-term events. In our case, this was partly balanced by the subsequent workshop one yr later. A more continuous form of stakeholder collaboration would incorporate the temporal dynamics of perspectives even further (Albert et al. 2012).

"Confirmability" describes the extent to which research findings are shaped by the respondents and not by researcher bias, motivation, or interests. Ways of establishing confirmability include documenting the procedures for producing and checking data throughout the research process, triangulating findings with additional data, and researchers' reflection on their own interest in and effect on the process (Lynam et al. 2007). Ample room for reflection was given during five research-group meetings before, in between, and after the workshops; scenario results were triangulated with insights from the larger research activities of our group in the area (www.ecosystemservices.de); all steps of the process were documented. However, it was partly unavoidable that researchers participated in the groups' discussions by providing examples to facilitate the discussion process, thus possibly slightly influencing the scenario outcomes.

\section{THE WAY AHEAD FOR CULTURAL LANDSCAPES}

Distinct cultural landscapes provide a plethora of ecosystem services to local communities; they are tightly coupled to regional economic development and to some aspects of quality of life, in particular through the cultural values that they offer. Participatory scenario development in a German region where people feel a strong cultural attachment to their landscape showed that landscape development may come to a crossroads over the next $30 \mathrm{yrs}$, with a possibility of either combined land abandonment and landscape industrialization scenarios or multifunctional, locally distinct landscape scenarios. Decisions about which trajectory will win out are, however, taken at and beyond local scales. Aspects of globalization, in particular the need for renewable energy supply, were stressed in all scenarios produced. However, performing this exercise with participants who have mostly benefitted from economic globalization has produced scenarios in which a committed civil society could be able to accompany and even shape such processes through local-level forces. Participants did not create backward-looking scenarios about past cultural landscapes. Rather, they imagined that larger scale processes beyond local reach can be capitalized on by developing a "spirit of invention" that embraces rather than inhibits landscape change and that assigns "modern" functions to valued "traditional" features of their cultural landscape (e.g., by using traditional orchards for renewable energy generation). The scenario narratives imagined that the most powerful way to develop and protect locally distinct cultural landscapes is to strengthen people's links to them, build social capital around them, and direct people's consumption patterns toward localized food production.

Responses to this article can be read online at: http://www.ecologyandsociety.org/issues/responses. $\mathrm{php} / 5802$

\section{Acknowledgments:}

We thank all stakeholders for participating in the three scenario workshops in 2011 and 2012, particularly mayors 
Verena Grötzinger and Michael Donth for providing local meeting venues. Kristen Evans convinced us of the added value of scenario approaches. Yvonne Dinter, Holger Gerdes, and Kathrin Trommler contributed to the preparation and performance of the workshops. Chris Hank substantially improved the language of the paper. Larissa Beumer, Franz Johann, Martin Mantel, and Aida García Rodríguez prepared illustrations. We gratefully acknowledge support by the German Ministry of Education and Research (FKZ 01UU0904A-D) and by the European Commission (Project HERCULES, grant agreement no. 603447, FP7-ENV-2013two-stage).

\section{LITERATURE CITED}

Albert, C., T. Zimmermann, J. Knieling, and C. von Haaren. 2012. Social learning can benefit decision-making in landscape planning: Gartow case study on climate change adaptation, Elbe valley biosphere reserve. Landscape and Urban Planning 105:347-360. http://dx.doi.org/10.1016/j. landurbplan.2011.12.024

Baker, J. P., D. W. Hulse, S. V. Gregory, D. White, J. Van Sickle, P. A. Berger, D. Dole, and N. H. Schumaker. 2004. Alternative futures for the Willamette River Basin, Oregon. Ecological Applications 14:313-324. http://dx.doi. org/10.1890/02-5011

Beinlich, B., and D. Manderbach. 1995. Die historische Landschafts- und Nutzungsentwicklung in Württemberg unter besonderer Berücksichtigung der Schwäbischen Alb. Beihefte zu den Veröffentlichungen für Naturschutz und Landschaftspflege in Baden-Württemberg 83:65-86.

Bieling, C., and T. Plieninger. 2012. Recording manifestations of cultural ecosystem services in the landscape. Landscape Research http://dx.doi.org/10.1080/01426397.2012.691469

Bieling, C., T. Plieninger, and H. Schaich. 2013. Patterns and causes of land change: empirical results and conceptual considerations derived from a case study in the Swabian Alb, Germany. Land Use Policy 35:192-203. http://dx.doi. org/10.1016/j.landusepol.2013.05.012

Burton, R. J. F., and G. Schwarz. 2013. Result-oriented agrienvironmental schemes in Europe and their potential for promoting behavioural change. Land Use Policy 30:628-641. http://dx.doi.org/10.1016/j.landusepol.2012.05.002

Chan, K. M. A., T. Satterfield, and J. Goldstein. 2012. Rethinking ecosystem services to better address and navigate cultural values. Ecological Economics 74:8-18. http://dx.doi. org/10.1016/j.ecolecon.2011.11.011

Enengel, B., M. Penker, A. Muhar, and R. Williams. 2011. Benefits, efforts and risks of participants in landscape comanagement: an analytical framework and results from two case studies in Austria. Journal of Environmental
Management 92:1256-1267. http://dx.doi.org/10.1016/j. jenvman.2010.12.005

Engel, S., and C. Palmer. 2011. Complexities of decentralization in a globalizing world. Environmental and Resource Economics 50:157-174. http://dx.doi.org/10.1007/ $\underline{\mathrm{s} 10640-011-9466-\mathrm{X}}$

Evans, K., W. d. Jong, and P. Cronkleton. 2008. Future scenarios as a tool for collaboration in forest communities. Sapiens 1:1-7.

Evans, K., S. J. Velarde, R. P. Prieto, S. N. Rao, S. Sertzen, K. Davila, P. Cronkleton, and W. de Jong. 2006. Field guide to the future. Four ways for communities to think ahead. Center for International Forestry Research (CIFOR), Nairobi, Kenya.

Farina, A. 2000. The cultural landscape as a model for the integration of ecology and economics. Bioscience 50:313320. http://dx.doi.org/10.1641/0006-3568(2000)050[0313: TCLAAM $\rceil 2.3 . C O ; 2$

Fischer, J., T. Hartel, and T. Kuemmerle. 2012. Conservation policy in traditional farming landscapes. Conservation Letters 5:167-175. http://dx.doi.org/10.1111/j.1755-263X.2012.00227. $\underline{\mathrm{X}}$

Gómez-Baggethun, E., S. Mingorria, V. Reyes-García, L. Calvet, and C. Montes. 2010. Traditional ecological knowledge trends in the transition to a market economy: empirical study in the Doñana natural areas. Conservation Biology 24:721-729. http://dx.doi.org/10.1111/ j.1523-1739.2009.01401.x

Henrichs, T., M. Zurek, B. Eickhout, K. Kok, C. RaudseppHearne, T. Ribeiro, D. van Vuueren, and A. Volkery. 2010. Scenario development and analysis for forward-looking ecosystem assessments. Pages 151-219 in N. Ash, H. Blanco, C. Brown, K. Garcia, T. Henrichs, N. Lucas, C. RaudseppHearne, R. D. Simpson, R. Scholes, T. P. Tomich, B. Vira, and M. Zurek, editors. Ecosystems and human well-being. A manual for assessment practicioners. Island Press, Washington, D.C., USA.

Herzog, F. 1998. Streuobst: a traditional agroforestry system as a model for agroforestry development in temperate Europe. Agroforestry Systems 42:61-80. http://dx.doi.org/10.1023/ A:1006152127824

International Panel on Climate Change (IPCC). 2012. Glossary of terms used in the IPCC fourth assessment report. IPPC, Geneva, Switzerland. [online] URL: http://www.ipcc. ch/pdf/glossary/ar4-wg2.pdf.

Jones, M. 2007. The European landscape convention and the question of public participation. Landscape Research 32:613633. http://dx.doi.org/10.1080/01426390701552753 
Kahn, H., and A. J. Wiener. 1967. The year 2000. Macmillan, New York, New York, USA.

Kaljonen, M., R. Varjopuro, M. Gielczewski, and A. Iital. 2012. Seeking policy-relevant knowledge: a comparative study of the contextualisation of participatory scenarios for the Narew River and Lake Peipsi. Environmental Science and Policy 15:72-81. http://dx.doi.org/10.1016/j.envsci.2011.10.006

Lincoln, Y. S., and E. G. Guba. 1985. Naturalistic inquiry. Sage Publications, Newbury Park, California, USA. http://dx. doi.org/10.1016/0147-1767(85)90062-8

Lindborg, R., M. Stenseke, S. A. O. Cousins, J. Bengtsson, A. Berg, T. Gustafsson, N. E. Sjodin, and O. Eriksson. 2009. Investigating biodiversity trajectories using scenarios-lessons from two contrasting agricultural landscapes. Journal of Environmental Management 91:499-508. http://dx.doi. org/10.1016/j.jenvman.2009.09.018

Loibl, W., and A. Walz. 2010. Generic regional development strategies from local stakeholders' scenarios-an Alpine village experience. Ecology and Society 15(3): 3. [online] URL: http://www.ecologyandsociety.org/vol15/iss3/art3/

Loupa Ramos, I. 2010. "Exploratory landscape scenarios" in the formulation of "landscape quality objectives." Futures 42:682-692. http://dx.doi.org/10.1016/j.futures.2010.04.005

Lynam, T., W. de Jong, D. Sheil, T. Kusumanto, and K. Evans. 2007. A review of tools for incorporating community knowledge, preferences, and values into decision making in natural resources management. Ecology and Society 12(1): 5. [online] URL: http://www.ecologyandsociety.org/vol12/iss1/ $\underline{\operatorname{art} 5 /}$

Matthews, R., and P. Selman. 2006. Landscape as a focus for integrating human and environmental processes. Journal of Agricultural Economics 57:199-212. http://dx.doi.org/10.1111/ j.1477-9552.2006.00047.x

Mayring, P. A. E. 2002. Einführung in die qualitative Sozialforschung. Eine Anleitung zu qualitativem Denken. Beltz, Weinheim, Germany.

O'Brien, K. L., and R. M. Leichenko. 2000. Double exposure: assessing the impacts of climate change within the context of economic globalization. Global Environmental ChangeHuman and Policy Dimensions 10:221-232. http://dx.doi.org/ http://dx.doi.org/10.1016/S0959-3780(00)00021-2

O'Brien, K. L., and R. M. Leichenko. 2003. Winners and losers in the context of global change. Annals of the Association of American Geographers 93:89-103. http://dx.doi. org/10.1111/1467-8306.93107

Pahl-Wostl, C. 2008. Participation in building environmental scenarios. Pages 105-122 in A. Alcamo, editor.
Environmental futures: the practice of environmental scenario analysis. Elsevier, Amsterdam, The Netherlands. http://dx. doi.org/10.1016/S1574-101X(08)00405-5

Palomo, I., B. Martin-Lopez, C. Lopez-Santiago, and C. Montes. 2011. Participatory scenario planning for protected areas management under the ecosystem services framework: the Doñana social"ecological system in Southwestern Spain. Ecology and Society 16(1): 23. [online] URL: http://www. ecologyandsociety.org/vol16/iss1/art23/

Penker, M., and H. K. Wytrzens. 2005. Scenarios for the Austrian food chain in 2020 and its landscape impacts. Landscape and Urban Planning 71:175-189. http://dx.doi. org/10.1016/j.landurbplan.2004.03.002

Pereira, E., C. Queiroz, H. M. Pereira, and L. Vicente. 2005. Ecosystem services and human well-being: a participatory study in a mountain community in Portugal. Ecology and Society 10(2): 14. [online] URL: http://www.ecologyandsociety. org/vol10/iss2/art14/

Peter, S., and K. Knickel. 2006. Empowerment of regional partnerships. The example of the regional action pilot program in Germany. disP 166:17-25. http://dx.doi.org/10.1080/025$\underline{13625.2006 .10556959}$

Peterson, G. D., T. D. Beard, B. E. Beisner, E. M. Bennett, S. R. Carpenter, G. S. Cumming, C. L. Dent, and T. D. Havlicek. 2003. Assessing future ecosystem services: a case study of the Northern Highlands Lake District, Wisconsin. Ecology and Society 7(3): 1. [online] URL: http://www.ecologyandsociety. org/vol7/iss3/art1/

Pierre, J., and G. Peters. 2000. Governance, politics and the state. Macmillan, New York, New York, USA.

Pinto-Correia, T., R. Gustavsson, and J. Pirnat. 2006. Bridging the gap between centrally defined policies and local decisionstowards more sensitive and creative rural landscape management. Landscape Ecology 21:333-346. http://dx.doi. org/10.1007/s10980-005-4720-7

Plieninger, T. 2012. Monitoring directions and rates of change in trees outside forests through multitemporal analysis of map sequences. Applied Geography 32:566-576. http://dx.doi. org/10.1016/j.apgeog.2011.06.015

Plieninger, T., O. Bens, and R. F. Hüttl. 2006. Perspectives of bioenergy for agriculture and rural areas. Outlook on Agriculture 35:123-127. http://dx.doi.org/10.5367/0000000$\underline{06777641624}$

Plieninger, T., and C. Bieling, editors. 2012. Resilience and the cultural landscape: understanding and managing change in human-shaped environments. Cambridge University Press, Cambridge, UK. http://dx.doi.org/10.1017/CBO9781139107778 
Plieninger, T., and C. Bieling. 2013. Resilience-based perspectives to guiding high nature value farmland through socio-economic change. Ecology and Society 8 in press.

Poschlod, P., and M. F. WallisDeVries. 2002. The historical and socioeconomic perspective of calcareous grasslandslessons from the distant and recent past. Biological Conservation 104:361-376. http://dx.doi.org/10.1016/S0006-3207 (01)00201-4

Prager, K. 2010. Local and regional partnerships in natural resource management: the challenge of bridging institutional levels. Environmental Management 46:711-724. http://dx. doi.org/10.1007/s00267-010-9560-9

Primdahl, J., and S. Swaffield. 2010. Globalisation and the sustainability of agricultural landscapes. Pages 1-15 in J. Primdahl, and S. Swaffield, editors. Globalisation and agricultural landscapes. Change patterns and policy trends in developed countries. Cambridge University Press, Cambridge, UK. http://dx.doi.org/10.1017/CBO9780511844928.002

Reenberg, A., T. Langanke, S. B. P. Kristensen, and T. S. Colding. 2010. Globalisation of agricultural landscapes: a land systems approach. Pages 31-56 in J. Primdahl, and S. Swaffield, editors. Globalisation and agricultural landscapes. Change patterns and policy trends in developed countries. Cambridge University Press, Cambridge, UK. http://dx.doi. org/10.1017/CBO9780511844928.004

Regierungspräsidium Tübingen. 2007. Nomination form of the UNESCO-Biosphere Reserve Swabian Alb. Ministerium für Ernährung und ländlichen Raum Baden-Württemberg, Tübingen, Germany.

Renes, J. 2011. European landscapes: continuity and change. Pages 117-136 in Z. Roca, P. Claval, and J. Agnew, editors. Landscapes, Identities and Development. Ashgate, Farnham, UK.

Schaich, H., C. Bieling, and T. Plieninger. 2010. Linking ecosystem services with cultural landscape research. GAIA 19:269-277.

Schaich, H., and T. Plieninger. 2013. Land ownership drives stand structure and carbon storage of deciduous temperate forests. Forest Ecology and Management 305:146-157. http:// dx.doi.org/10.1016/j.foreco.2013.05.013

Selman, P. H. 2012. Sustainable landscape planning: the reconnection agenda. Routledge, Milton Park, New York, USA.

Seto, K. C., A. Reenberg, C. G. Boone, M. Fragkias, D. Haase, T. Langanke, P. Marcotullio, D. K. Munroe, B. Olah, and D. Simon. 2012. Urban land teleconnections and sustainability. Proceedings of the National Academy of Sciences of the United States of America 109:7687-7692. http://dx.doi.org/10.1073/ pnas.1117622109
Soliva, R., K. Ronningen, I. Bella, P. Bezak, T. Cooper, B. E. Flo, P. Marty, and C. Potter. 2008. Envisioning upland futures: stakeholder responses to scenarios for Europe's mountain landscapes. Journal of Rural Studies 24:56-71. http://dx.doi. org/10.1016/j.jrurstud.2007.04.001

Termorshuizen, J. W., and P. Opdam. 2009. Landscape services as a bridge between landscape ecology and sustainable development. Landscape Ecology 24:1037-1052. http://dx.doi.org/10.1007/s10980-008-9314-8

Tress, B., and G. Tress. 2003. Scenario visualisation for participatory landscape planning-a study from Denmark. Landscape and Urban Planning 64:161-178. http://dx.doi. org/10.1016/S0169-2046(02)00219-0

Van Berkel, D. B., S. Carvalho-Ribeiro, P. H. Verburg, and A. Lovett. 2011. Identifying assets and constraints for rural development with qualitative scenarios: a case study of Castro Laboreiro, Portugal. Landscape and Urban Planning 102:127-141. http://dx.doi.org/10.1016/j.landurbplan.2011.03.016

Verburg, P. H., D. B. van Berkel, A. M. van Doorn, M. van Eupen, and H. A. R. M. van den Heiligenberg. 2010. Trajectories of land use change in Europe: a model-based exploration of rural futures. Landscape Ecology 25:217-232. http://dx.doi.org/10.1007/s10980-009-9347-7

Walz, A., C. Lardelli, H. Behrendt, A. Gret-Regamey, C. Lundstrom, S. Kytzia, and P. Bebi. 2007. Participatory scenario analysis for integrated regional modelling. Landscape and Urban Planning 81:114-131. http://dx.doi. org/10.1016/j.landurbplan.2006.11.001

Weis, M., and K. Hülemeyer. 2011. Landschaftsszenarien für den Hochschwarzwald vor dem Hintergrund früherer Entwicklungen-Konsequenzen von Nutzungsänderungen für Biodiversität und Landschaftsästhetik. Natur und Landschaft 86:285-297.

Wollenberg, E., D. Edmunds, and L. Buck. 2000. Using scenarios to make decisions about the future: anticipatory learning for the adaptive co-management of community forests. Landscape and Urban Planning 47:65-77. http://dx. doi.org/10.1016/S0169-2046(99)00071-7

Young, O. R., F. Berkhout, G. C. Gallopin, M. A. Janssen, E. Ostrom, and S. V. D. Leeuw. 2006. The globalization of socioecological systems: an agenda for scientific research. Global Environmental Change 16:304-316. http://dx.doi.org/10.1016/ j.gloenvcha.2006.03.004 